\title{
Judicial Enforcement of Union Disciplinary Fines
}

Union fines, a traditional instrument of discipline, ${ }^{1}$ are usually enforced by threat of expulsion. ${ }^{2}$ Ordinarily a member would rather pay his fine than accept the role of outcast. On occasion, however, expulsion holds no terror for the fined member. A strikebreaker would probably rather get out than pay up. By crossing the picket-line he already would have affronted his colleagues; ouster could not lower his social standing further. And from an economic standpoint a union member in a TaftHartley union shop would actually be better off after expulsion, for he would keep his job but no longer owe union dues. ${ }^{3}$ Thus unions may have to repair to the courts to collect disciplinary fines.

At common law, courts upheld the unions' infrequent attempts to sue; ${ }^{4}$ treating unions as voluntary associations, they considered fines valid contractual debts. ${ }^{5}$ But the common law rule may no longer govern, for the Wagner and Taft-Hartley Acts have substantially reordered union-employee relations. The National Labor Relations Board considers judicial enforcement of fines compatible with the federal stat-

1. See I. D. Willcutt \& Sons Co. v. Driscoll, 200 Mass. 110, 85 N.E. 897 (1909); Bossert v. Dhuy, 221 N.Y. 342, 117 N.E. 582 (1917).

2. See L. D. Willcutt \& Sons Co. v. Driscoll, supra note 1, at 123, 132-38, 141, 85 N.E. at 903, 907-09, 910-11 (dissenting opinion). Before the enactment of the Taft-Hartley Act enforcement of fines could be very effective since loss of union membership might cost an emplojee his job. See id. at 123,85 N.E. at 903 . Prior to 1947 it was legal for unions and employers to sign "closed-shop" contracts, which were expressly authorized by" the National Labor Relations Act (Wagner Act) \& 8(3), 49 Stat. 452 (1935). Current Iaw forbids a union to cause employer discrimination against a union member beause he refuses to pay a fine. Labor Management Relations Act (Taft-Hartley Act) \& 8(b)(2), 61 Stat. 141 (1947), 29 U.S.C. \$ 158(b)(2) (1964); Local 4, United Slate Workers Ass'n, 140 N.L.R.B. 384 (1962).

3. Sections $8(\mathrm{a})(3)(\mathrm{B})$ and $8(\mathrm{~b})(2)$ of the Taft-Hartley Act prevent a union from requiring an employee's discharge on the ground of non-membership if the cmplojec was expelled from the union for any reason other than failure to tender dues. 61 Stat. 140, 141 (1947), 29 U.S.C. $\$ \S 158(\mathrm{a})(3)(B), 158(\mathrm{~b})(2)$ (1964).

4. Suits on union fines were rare for at least two reasons. First, cren when the union secured a valid claim, the cost of a suit outweighed the benefits of a recovery. The money involved was seldom significant, and the suit was hardly likely to induce the defendant to rejoin the union. Most unions simply wrote off members who vere expelled for refusing to pay fines. See L. D. TWillcutt \& Sons Co. v. Driscoll, supra note 1, at 141 , 85 N.E. at 910-11 (1908). Second, a union member could prevent the union from securing a valid claim against him by resigning from membership before engaging in conduct which would incur a fine. A union member who was willing to suffer expulsion for doing as he pleased lost little by resigning before committing an offense for which he vould be fined and expelled. Ultimately, therefore, unions had to depend on expulsion with its possible attendant loss of job to enforce discipline.

5. Lodge 78, Int'l Ass'n of Machinists v. Engel, $32 \mathrm{CCH}$ Lab. Cas, 70,746 (Civil Ct., Milwaukee County, Wis. 1957); 6 Ax. Jur. 2d, Associations and Clubs $\$ 8$ (1963). See generally Summers, Legal Limitations on Union Discipline, 64 HARv. L. REv. 1019, 1054-56 (1951). 
utory scheme. ${ }^{6}$ But the Seventh Circuit has disagreed, in Allis Chalmers v. $N L R B$ a case now before the Supreme Court on certiorari. ${ }^{7}$

In Allis-Chalmers the United Automobile Workers sued members of the union who had refused to pay fines levied for strikebreaking. By a 4-3 vote, the Seventh Circuit held that enforcement of the fines would be an unfair labor practice under Taft-Hartley. ${ }^{8}$ The case turns on $\S 8(\mathrm{~b})(1)(\mathrm{A})$ and $\S 7$ which forbid unions to "restrain or coerce" employees in the exercise of their right to "refrain" from collective activities like strikes. ${ }^{9}$

On a literal reading, the two sections go beyond common law protection: the right to refrain calls for unqualified freedom of choice. This interpretation would bar unions from ever suing strikebreakers. An alternative reading would make fines collectible in court, but only if membership in the union is genuinely voluntary. This is the theory of the common law-the worker should be free to join or not to join the union, but once a member he can be bound by its rules. ${ }^{10}$ So con-

6. Local 248, UAW (Allis-Chalmers Mfg. Co.), 149 N.L.R.B. 67 (1964); Local 283, UAW (Wisconsin Motor Corp), 145 N.L.R.B. 1097 (1964).

7. 358 F.2d 656 (7th Cir.), cert. granted, 385 U.S. 810 (1966).

8. The case arose when a number of employees at two Allis.Chalmers plants in Wisconsin continued to work during strikes called by the UAW locals which represented the plants. The employees at both plants were covered by union-shop contracts rcquiring them to join the union within thirty days of hiring and to "remain members of the Union to the extent of paying dues." None of the employees who refused to strike had been expelled from the union or had attempted to resign. After the termination of the strike those union members who had continued to work were called before union trial boards and fined amounts ranging from $\$ 20$ to $\$ 100$, but many of the fined cmployees refused to pay. Wisconsin courts have enforced union fines in similar circumstances, Local 756, UAW v. Woychik, 5 Wis. 2 d 528, 93 N.W.2d 336 (1958), so a test suit was brought against one employee in the Milwaukee County Court. The union was successful, and the NLRB upheld the recovery against a charge that the union had committed an unfair labor practice by bringing the suit. Local 248, UAW (Allis-Chalmers Mfg. Co.), 140 N.L.R.B. 67 (1964).

9. 61 Stat. 140,141 (1947), 29 U.S.C. $\$ \S 157,158(\mathrm{~b})(1)(\mathrm{A})(1964)$. It is well settled that strikes are activities encompassed by $\$ 7$ and thus subject to the protection provided by $\S 8(\mathrm{~b})(\mathrm{I})(\mathrm{A})$. Local 1778, Glaziers, I34 N.L.R.B. 702 (1961); International Longshorcmen's Union, 79 N.L.R.B. 1487 (1948). The undetermined question is whether a suit on a finc constitutes "restraint or coercion" within the meaning of $\S 8(\mathrm{~b})(1)(\mathrm{A})$ or is a legitimatc form of union discipline sanctioned by the proviso to the section.

10. Prior to its decision to permit suits on union fines the NLRB had never allowed enforcement of a union rule which entailed a penalty going beyond forfeiture of member. ship privileges. For example, the NLRB has held that it is a violation of $\$ 8(\mathrm{~b})(1)(A)$ for a union to punish members who refuse to participate in a strike by having them discharged, Local 1778, Glaziers, supra note 9, or by preventing them from obtaining work, local 207, Warehouse Workers' Union, 118 N.L.R.B. 342 (1957). Both of these decisions can be explained on the alternate ground that the punishments complained of violated $\S 8(\mathrm{~b})(2)$, 61 Stat. 141, 29 U.S.C. $\$ 158(\mathrm{~b})(2)(1964)$. Still, the findings of violations of $\& 8(\mathrm{~b})(1)$ (A) aro indicative of the scope of the protection provided by the section. Further, there are other cases in which unions violated $\S 8(\mathrm{~b})(1)(\bar{A})$ alone by imposing economic sanctions against delinquent members. For example, a union violated $\$ 8(\mathrm{~b})(\mathrm{I})(\mathrm{A})$ by threatening to deprive two members of the benefits of an insurance plan administered jointly by the employer and the union for failure to pay a disciplinary fine. Local 479, Amalgamated Clothing Workers (Jaymar Ruby, Inc.), I51 N.L.R.B. 555 (1965). 
strued, the Act would allow judicial enforcement of fines in all open shop situations.

When a union shop is in force, the problem is more complicated. Under Taft-Hartley's § 8(a)(3), a collective agreement may require as a condition of employment that every employee acquire union "membership" after he has been hired. ${ }^{11}$ But other sections of the Act may enable an employee to reject the full duties of membership and satisfy his union shop obligations merely by paying dues. If this construction is correct, actual membership in a union is voluntary even under a union shop.

The Allis-Chalmers court split on precisely this issue. The majority read the statute literally: the law says that membership may be required as a condition of employment; hence membership is not voluntary. The minority, however, pointed to Taft-Hartley's § 8(b)(2), which allows the union to have an employee fired for non-membership only if the sole material condition of membership is payment of dues and initiation fees. Recently, the Seventh Circuit held that an employee who tendered dues and fees to his union, but refused to take an oath of allegiance, could not be discharged under a union shop clause.12 Accordingly, reasoned the Allis-Chalmers minority, a new employee is free to spurn membership so long as he pays dues. If instead he accepts membership, he has voluntarily exposed himself to the union's power of discipline, and can be sued on a fine.

In one sense, the minority view is correct: recent case law does suggest that an employee may decline formal membership. ${ }^{13}$ But only

The foregoing cases suggest an inconsistency in the NLRB's position that suits on fines are not barred by $\$ 8(\mathrm{~b})(1)(A)$. Logically it is difficult to distinguish between the cocrcion which results from loss of employment or insurance benefits and that which results from loss of a suit on a fine. The conceptual basis for holding that a union may cnforce a rule imposing a legal liability but not one imposing other forms of cconomic penalties is not clear.

11. 61 Stat. 140 (1947), as amended, 29 U.S.C. $\$ 158(a)(3)$ (1964).

12. Union Starch \& Refining Co. v. NLRB, 186 F2d 1008 (7th Cir.), cert. denied, 342 U.S. 815 (1951).

13. In NLRB v. General Motors Corp., 373 U.S. 734 (1963), the Court found that an agency-shop agreement which required all employees to pay union dues and in return allowed them to share equally in union strike, educational, and retirement benefits but which conditioned participation in union meetings and voting on union membership. made freely available at the option of the cmployce, was the practical equivalent of a Taft-Hartley union-shop agreement. In Retail Clerks Int'I Ass'n, Loal 1625 v. Schermerhorn, 373 U.S. 746 (1963), the Court carried the analogy between the agency shop and the union shop further by holding that $\S 14(\mathrm{~b})$ of Taft-Hartley, G1 Stat. 151 (1947), 29 U.S.C. $164(\mathrm{~b})$ (1964), permitted the states to outlaw the agency shop cren though \& 14(b) is written in terms of "agreements requiring membership in a labor organization" only (emphasis added). In sum, the Court appears to have concluded that the "membership" requirement of a union-shop agreement is satisfied by mere tender of the required initiation fee and dues, the employee being under no further obligation whatsoever to 
regular readers of F.2d would know this point of law. Often the union shop contract says that "membership" is required;14 for that matter, so does the Taft-Hartley Act. Even a carefully explicit union security clause, like the UAW's, ${ }^{15}$ will probably escape the attention of the average worker. Most new employees will assume that they have to join the union and will acquire membership without giving the matter a second thought.

Rules limiting resignation also belie the voluntary character of union membership. Even a member who joined deliberately may find it difficult to change his mind. For example, under a UAW constitutional provision upheld by the First Circuit, all resignations must be submitted by registered mail to the financial secretary of the member's local within ten days of the end of the fiscal year.10 Rules like these bind a new member to a choice made at the moment of his slightest acquaintance with the union. If courts can enforce obligations on dissidents thus locked into membership, the right to refrain from union activities will be illusory.

To be sure, some restraints on resignation are justified. The union should be able to require that a reluctant member quit before breaking the rules, not merely before paying the fine. And it may even say that a man who takes part in a strike vote is bound by it. But if membership is to be genuinely voluntary, the union must offer dissidents a continuing, realistic choice to opt out of union solidarity.

In sum, it is unrealistic to assimilate the common law's receptivity to union suits on fines with the objectives of Taft-Hartley. The Court could, of course, condition enforcement in each case on a finding that the delinquent employee's membership was voluntary. Courts would then have to scrutinize the circumstances of his entry into the union and the constraints limiting his opportunity to resign. To minimize subterfuge, the burden could be placed on the union to show that the employee knew of his right to refrain from membership. But this approach would take the judiciary down a tedious path. More important, it would offer quite uncertain protection to the individual worker. Anything less than a flat prohibition on judicial enforcement

the union. See NLRB v. General Motors Corp., supra, at 748. The NLRB has adopted this view explicitly. Marlin Rockwell Corp., 114 N.L.R.B. 553 (1955).

14. See the model union-shop clause drawn by the NLRB for the guidance of bargain. ing representatives, Keystone Coat, Apron \& Towel Supply Co., 121 N.L.R.B. 880, 885 (1958).

15. The contracts involved in the Allis-Chalmers case required employees to "remain members of the Union to the extent of paying dues." $358 \mathrm{~F} .2 \mathrm{~d}$ at 657 .

16. NLRB v. International Union, UAW, 320 F.2d 12 (lst Gir. 1963). 
of union fines will assure that some workers, perhaps more than a few, will inadvertently subject themselves to a choice between liability and bending before some unwelcome union activity.

An across-the-board bar to union suits on fines will leave unions with no substantial sanction to coerce any member willing to accept expulsion. Free-booters and cantankerous employees in union shops might be able to take undue advantage of their immunity from punishment. Under $\S \S 8(a)(3)^{17}$ and $8(b)(2),{ }^{18}$ if a union with a union security clause expels a member for any reason other than failure to pay dues-for example, for failure to pay a disciplinary fine-the union forfeits its right to require that he pay dues as a condition of employment. ${ }^{10}$ Consequently, offending union discipline would be the optimal way for a worker to escape the single obligation which Taft-Hartley's union shop proviso meant to impose on him-the duty of giving financial support to his bargaining representative. 20 If he had enough gumption, he could withdraw from the union whenever he wished to ignore a particular order and then rejoin as he pleased until the union was fed up enough to forfeit its right to dues.

This subversion of Taft-Hartley's aim to eliminate "free riders" can be avoided, if unions can suspend a delinquent employee's membership privileges without forfeiting its right to collect the employee's dues. Suspension would not be tantamount to expulsion; all normal membership benefits would automatically revert as soon as the delinquency ceased. To prevent abuse of this power, Title I of the LandrumGriffin Act ${ }^{21}$ provides an adequate set of checks. Its terms will protect the worker from arbitrary or unequal treatment, suppression of his right of free speech, and improper disciplinary action. Violation of any rule permitted by the proviso to $\S 101(a)(2)^{22}$ would be proper grounds for suspension if the disciplinary action were taken in accordance with the due process requirements of $\S 101(a)(5) .{ }^{23}$ Given this adjustment, a meaningful right to refrain can be granted the worker without robbing the union of the minimal security which Taft-Hartley was intended to provide.

17. 61 Stat. 141 (1947), 29 U.S.C. § 158(a)(3)(B) (1964).

18. 61 Stat. 141 (1947), 29 U.S.C. \& 158(b)(2) (1964).

19. See NLRB v. National Automotive Fibres, Inc, 277 F.2d 779 (9th Cir. 1960).

20. Radio Officers' Union v. NLRB, 347 U.S. 17, 40.41 (1954).

21. Labor-Management Reporting and Disclosure Act $\S \S 101-05,73$ Stat. 522 (1959), 29 U.S.C. $\$ \S 411-15(1964)$.

22. 73 Stat. 522 (1959), 29 U.S.C. $\$ 411$ (a)(2) (1964). The proviso preserves to unions the right "to adopt and enforce reasonable rules as to the responsibility of crery member toward the organization as an institution and to his refraining from conduct that vould interfere with its performance of its legal or contractual obligations."

23. 73 Stat. 523 (1959), 29 U.S.C. $\$ 411(a)(5)(1964)$. 